\title{
Communication Strategies in the 2020 Local Election Stages Socialization During the Covid-19 Pandemic
}

\author{
http://dx.doi.org/10.25008/jkiski.v5i2.459
}

\author{
Ni Made Ras Amanda Gelgel ${ }^{*}$, Kadek Dwita Apriani², Richard T. Ginting ${ }^{3}$ \\ ${ }^{1}$ Department of Communication Science, Universitas Udayana \\ ${ }^{2}$ Department of Political Science, Universitas Udayana \\ ${ }^{3}$ Department of Library and Information Science, Universitas Udayana \\ Jl. PB Sudirman Denpasar, Bali 80223 - Indonesia \\ *Corresponding author: rasamanda13@unud.ac.id
}

\author{
Submitted: November 19, 2020, Revised: December 04, 2020, Accepted: December 25, 2020 \\ Accredited by Kemristekdikti No. 28/E/KPT/2019
}

\begin{abstract}
:
Indonesia has decided to hold simultaneous local elections on December 9, 2020, even though the country and the rest of the world still face the COVID-19 pandemic. The local election stages have begun in June 2020 by forming a unit to update data of voters and socialize how to hold the elections during the pandemic. This paper aims to build communication strategies in socializing how to hold the elections during the COVID-19 pandemic. The results were obtained using the survey method involving 440 respondents in Denpasar in September 2020. The communication strategy is a combination of offline and online mediums. Despite a policy to stay at home, data shows that residents of Denpasar still needed offline mediums such as billboards and banners. In addition, they also searched for information about the election through printed advertisements and television advertisements. To ensure the smooth socialization of election process, the General Election Commission (KPU) in Denpasar uses accounts in social media platforms such as Instagram and Facebook in collaboration with parties that have a large number of followers or mass media that have accounts in social media with a large number of followers. However, almost all respondents do not follow the official account of KPU Denpasar. Uniquely, in Denpasar, some potential voters still rely on community leaders and figures in searching for information about the local election. To that end, to build communication strategies, these community leaders and figures should be involved. Data also show that online meeting like zoom, google meet, or Webex meeting is not sufficient.
\end{abstract}

$\underline{\text { Keywords: communication strategy; community leaders; local election; socialization; covid-19 }}$

\section{Introduction}

The perspective of whether the local election will continue to be held amid the Pandemic sparks pros and cons. If it continues, there will be a compromise point on the implementation that can reduce the quality of the elections themselves (James \& Alihodzic, 2020). South Korea is a country that continues to hold general elections during the Pandemic and can be prosperous despite the looming risk of COVID-19 (KIM, 2020).

This is different from that of the United States, where the COVID-19 been an issue or discourse that affects the presidential election. The high number of COVID-19 sufferers was considered to bring down the incumbent, Donald Trump (Baccini et al., 2020).

Simultaneous regional/local head elections or Pilkada in Indonesia, which had originally been delayed due to the Covid-19 Pandemic, were finally decided to continue in 2020 , to be precise, on December 9, 2020. The Commission II of the Indonesian House of Representatives (DPR RI) requested that the Pilkada 2020 continues under stringent health protocols, and violators must 
receive strict sanctions (Kompas.com, 2020). Pilkada was held in 270 regions at the end of 2020, covering nine provinces, 224 regencies, and 37 cities, with 105 million registered voters.

The General Election Commission (KPU), as the organizing institution, then rushed again with a new homework, that is to ensure that Pilkada would run in accordance with the rules and has thus far not had an impact on the increasing number of people infected with the COVID-19. Under KPU Regulation (PKPU) number 13 of 2020, the health protocols to contain the spread of COVID-19 is regulated for the purpose of safe Pilkada.

Hence, KPU as an organizer has additional tasks to convince voters not to worry about coming to the polling station (TPS). Head of KPU Arief Budiman emphasized that all KPU officers and TPS officers will follow strict health protocols, starting from providing hand-washing facilities and hand sanitizers, checking body temperature, providing gloves, to using personal protective equipment (PPE). The PKPU also regulates the voting time for voters to avoid crowds at TPS. For this reason, the KPU is targeting $77.5 \%$ voter turnout in the 2020 Pilkada. However, Arif Budiman emphasized the importance of socializing health protocols at TPS and Pilkada implementation as an essential point of a successful Pilkada during the pandemic (Beritasatu.com, 2020).

Based on PKPU number 13 of 2020, article 58 , campaign activities are prioritized through social media and online media. Article $88 \mathrm{C}$ states that bring me to prohibit the campaign team from carrying out mass gathering activities in large numbers (bbc.com, 2020). As for the implementation, the Indonesian KPU expects the organizers to take effective socialization steps more creatively to comply with health protocols, for example, conducting online socializations or through community communities in cyberspace (baliexpress.jawapos, 2020). With massive enough socialization, it is hoped that voters will understand and feel more confident to attend the TPS (Departasari, 2020).

Online socialization, in the Election Supervisory Agency (Bawaslu)'s view, will bring its problems. Bawaslu identifies that poor internet infrastructure will be the central point of problems in the Pilkada process. Bawaslu itself has identified 67 urban districts that are prone to bad aspects of internet infrastructure (bbc.com, 2020). This confirms that socialization during the pandemic period played a very important role, especially how to socialize and through what socialization was carried out to prospective owners.
The socialization is expected to provide understanding and knowledge about a series of activity programs to be implemented. Pilkada socialization by the KPU is considered to be a variable in influencing the level of participation in the Pilkada (Meyliana \& Erowati, 2020). Bawaslu also faces the same homework. Bawaslu in Pemalang, Central Java, for example, strengthens socialization and supervision through its social media and coordinates with related parties (Mutiarasari, 2020).

The Denpasar City KPU is one of the organizers of Pilkada in 270 regions on December 9, 2020. The Denpasar City KPU uses a variety of media that can be accessed and used and maximized in the current pandemic situation. Some of the strategic steps taken include holding online seminars on the platform YouTube, optimizing the installation of billboards in every corner of the city, and maximizing several platforms' official social media owned by the Denpasar City Commission, such as Instagram, Twitter, and Facebook. Apart from that, the Denpasar City KPU has also made an unusual approach with Denpasar's mass media by holding a media gathering.

Finally, the steps taken by the Denpasar City KPU are by interacting with youth groups throughout the city of Denpasar using a zoom platform. It is just that, based on the observations made, it was found that a handful of people only attended some events that were held online.

A useful communication model is needed to disseminate the stages and technical health protocols during Pilkada stages and at the time of voting. Are online communication methods the most effective? Or does the society want something else? The purpose of this research is to find out the most appropriate communication strategy to socialize Pilkada in Denpasar City during the COVID-19 pandemic.

\section{Theoretical Framework}

The dissemination of electoral stages and technical health protocols in polling stations is critical in the era of the COVID-19 pandemic. Political socialization is one of the factors that can determine the success of Pilkada. Wibowo et al. emphasized that an offensive strategy, or new programs that are different from the previous socialization model are needed. The dissemination is not only the responsibility of the organizers but also other institutions in socializing the stages and techniques of voting, especially during the Covid19 pandemic (Hergianasari, 2020).

It is even estimated that this pandemic will encourage the KPU to enter the digital election system (Persada, I'ib Sutera Aru, 2020). However, 
socialization can also become a massive social movement through the use of social media as a form of interaction, communication, and information dissemination (Sahputra, et.all, 2020).

Social media has been widely used in political campaigns (Saraswati, 2018), both by regional head candidates and political parties (Amirudin, 2015) up to the presidential election in Indonesia (Hasfi et al., 2017). One of them is Jakarta gubernatorial election where Anies Baswedan competed with Basuki Tjahja Purnama (Murwani, 2018).

This shows that there has been a change in the form of communication between candidates and voters in the 20th century, now voters can be more actively involved in campaigns through new media (Moraru \& Rusu, 2017). Political communication, according to him, is a communication process that was directed at achieving an influence so that the issues discussed in communication activities can bind all citizens who have been jointly determined by political institutions (Santoso et al., 2020).

Politics translated as a collective activity, and political communication is a way to create social and governmental conditions and the state in a state of peace and harmony. There is also feedback or response to what was conveyed in political communication and what messages are conveyed in the communication process itself. Responses or feedback, according to him, can be divided into three, namely evaluating the communicant's quality or source, helping to stimulate change, and giving appreciation.

\section{Material and Methodology}

This research uses quantitative methods because quantitative political research uses measurement in the analysis of behavior or attitudes (Harison, 2009: 15). The primary data collection was carried out by structured interviews with respondents using a google form questionnaire. Based on the objectives, this research is a descriptive study (Singarimbun and Efendi, 1989: 4). The research location includes all sub-districts in Denpasar City, namely South Denpasar, East Denpasar, North Denpasar, and West Denpasar.

This research was conducted effectively for five weeks, starting with preparation, data collection, data processing, and data analysis. A population is a group or group of objects that are the target of research (Bungin, 2008: 99). The population in this study is the people of Denpasar City who meet the requirements to become voters in the 2020 Denpasar Mayoral Election, such as having a Denpasar City ID card, aged 17 years or over, and included in the Denpasar City Pilkada Voter List.

The total population is 444,929 voterssamples to represent the population using the Slovin formula. Slovin formula is sample equal to population divided by the sum of 1 by the population times the margin error square.

\section{$n=N /(1+N(e 2)$}

Where :

$\mathrm{n}:$ Sample

$\mathrm{N}$ : Population

e : Standard error or critical value

If it was entered in the formula with $\mathrm{e}=0.05$, then nor the minimum quantity is obtained is 399.640 rounded to 400 . To anticipate the questionnaires that are not collected, the researchers reserve 5 percent of the minimum samples, namely 20 samples, so that the number of samples is 420 . The sample size is causing the Margin of Error in this study to be 5\%, at a 95\% confidence level (Vaus. D A Sydney, 1991).

This study's sampling technique was quota sampling based on the age cohort in each sub- district in Denpasar. Denpasar City has four subdistricts. In each of these districts, an equal number of samples were taken, namely as many as 105 people. In each sub-district, respondents were taken in proportion to age categories. In this study, age categorization is based on generation theory, which states those baby boomers, generation $X$, Generation Y, and Generation Z (Howe, N. \& Strauss, W. 1991). More details about the stages in quota sampling in research can be seen in the following figure. 


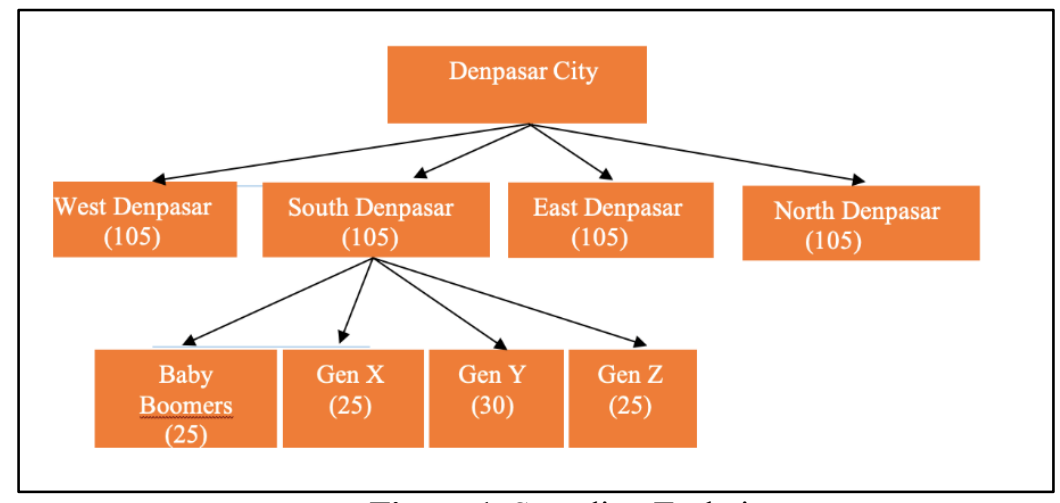

Figure 1. Sampling Technique

The picture above illustrates the sampling flow to the respondent. It is shown that all subdistricts are taken as sample areas, then in each district, respondents are taken based on age quota on the condition that the respondent is a Denpasar resident who lives in the district concerned, has the right to vote in the Denpasar Pilkada or is registered in the Denpasar City DPT / DPS 2020 obtained from this survey, analyzed with descriptive statistics, namely frequency tables and cross tables. The frequency table is used to study the frequency distribution of the research variables. The cross table serves to find out whether one variable determines or is related to other variables. (Mars and Stoker, 2010: 269)

\section{Result and Discussion}

The findings of this study will be divided into several main parts, namely (1) a portrait of the knowledge of the Denpasar community up to September 2020 regarding the Regional Election in the region, which was initially held in December
2020, and (2) the consumption pattern of the Denpasar people; (3) public information related to the Pilkada of Denpasar city during the Pandemic. Departing from these three subsections, then an analysis of the communication model in the 2020 Denpasar Pilkada socialization can be carried out so that the best communication model in the Pilkada in the Pandemic era can be concluded.

\section{Portrait of Public Knowledge about Pilkada Denpasar}

More than $75 \%$ of voters in the city of Denpasar already know about the 2020 Pilkada, and its region (Denpasar city) is included in the 270 regions that held Pilkada this year. This figure reflects that the public's knowledge of the electoral momentum at the local level, which will be held in the next two months, is quite good. Only $24 \%$ of the total respondents stated that they did not know about the 2020 Pilkada will be held simultaneously. Data on this can be seen in Figure 2 below.

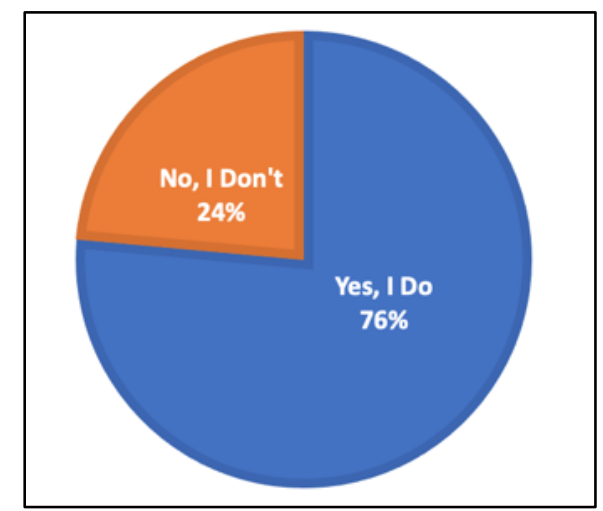

Figure 2. Denpasar Community Knowledge about the 2020 Pilkada Simultaneously

Even though most of the residents of Denpasar know that the Pilkada will be held in the city of Denpasar on December 9, 2020, the number of those who follow the issue of Pilkada is relatively lower. This is evident from three indicators: (1) the knowledge of the Denpasar community that the December 2020 Pilkada was the result of a postponement of Pilkada which had originally been scheduled for September 2020 due to the COVID-19 pandemic. (2) The number of voters who claimed to find out the track record of candidates for mayor and deputy mayor that contested in the 2020 Pilkada. (3) The number of voters who claimed to have checked names on the Final Voters List (DPT) ensures their voting rights. 
Data on these three indicators were presented in Figures 3, 4, and 5 below.

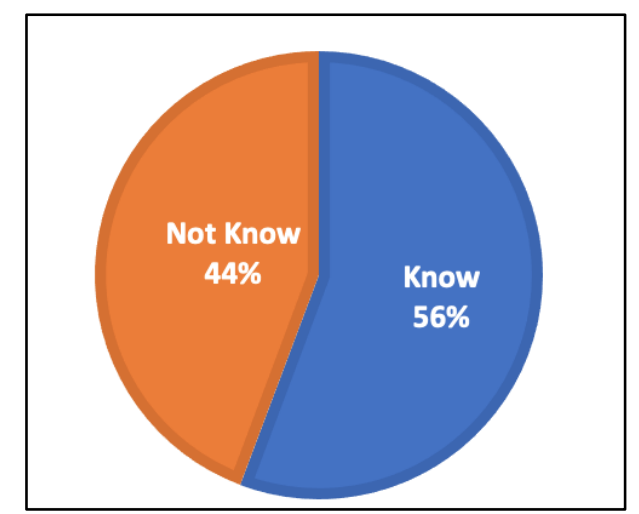

Figure 3. Knowledge of Postponement of Pilkada during Covid-19

The data presented in Figure 3 shows that $44 \%$ of the people of Denpasar do not know that the Denpasar Pilkada on December 9, 2020, had originally been scheduled to be held in September 2020. The simultaneous postponement of the Pilkada occurred nationally due to the COVID 19 pandemic. This data is one indicator that is able to state that the people of Denpasar are not too enthusiastic about the Pilkada issue.
The next indicator that is still related to the enthusiasm of the people of Denpasar for the Pilkada is voters' enthusiasm in finding out the track records of candidates for regional heads and deputy regional heads who will compete in the contestation of local leaders. The data in Figure 4 shows that only $50 \%$ of voters are trying to find out through various media about their regional leaders' track records.

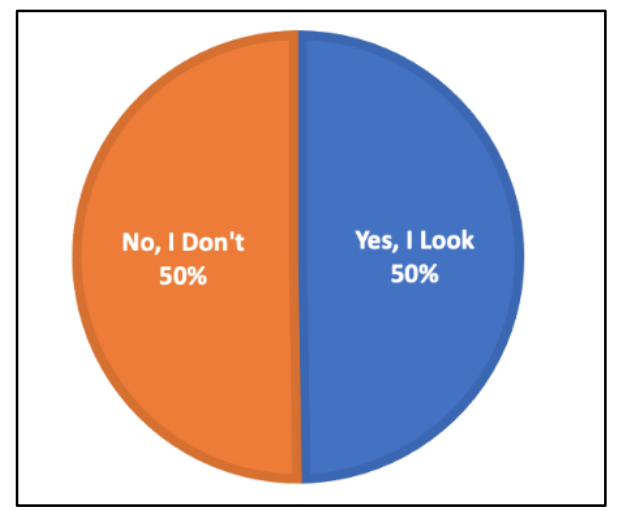

Figure 4. Finding Out about Candidates for Regional Head in Denpasar

The $50 \%$ obtained from the survey conducted two months before the Pilkada implies that only $1 / 2$ of the population of Denpasar still considers the Pilkada to be an essential momentum, and that they look for information about the candidates. When the field survey was carried out, the Denpasar Pilkada was in the nomination stage, so mass media coverage of the names of candidates was relatively easy to find. However, the public's interest in tracing about candidates was not that high.
The next indicator used to see the public's response to a contest is awareness to check whether or not the name concerned is on the voter list. It was known that checking the voter list can be done online at https://lindungilateralpilihmu.kpu.go.id.

The KPU of Denpasar's city has carried out reasonably intense socialization in checking the voter lists (DPT) online. Hence, the survey results show, only $33.6 \%$ or about $1 / 3$ of voters in the city of Denpasar have ever checked their names on the voter list for the 2020 Denpasar mayoral election (Pilwali). 




Figure 5. Have Checked DPT to Ensure that Registered as Voters

From some of the data and indicators described above, it can be seen that public enthusiasm for the Pilkada of Denpasar city tends to be low, thus strengthening the notion that currently, the public is not concentrating on regional head elections, but on the pandemic. Later there was concern that if the Pilkada was to be held, then TPS would become a new cluster of COVID-19 transmission. Crowds that can increase the risk of COVID-19 transmission become cause for concern and there are suspicions that the voter turnout of the simultaneous Pilkada this year will decline. For Denpasar in particular, and Bali in general, the target of voter turnout was $82 \%$. This target is undoubtedly complicated to achieve if the socialization is not massive, and there is no innovation in the applied communication model.

On the other hand, concerns over polling stations' safety were answered by the implementation of health protocols at polling stations by the organizers; however, the socialization of health protocols at polling stations was not optimal. The number of people who know nine new things at TPS during the pandemic also only ranges from $29 \%$ to $59 \%$. Data of the Denpasar community's knowledge about nine new things at TPS related to the COVID health protocol were presented in table 1 below.

Table 1. Voters Knowledge of the Application of Nine New Things in TPS

\begin{tabular}{|l|c|c|}
\hline \multicolumn{1}{|c|}{ Knowledge of Health Protocols at TPS } & Know & Not Know \\
\hline $\begin{array}{l}\text { Limiting the number of voters to 500 } \\
\text { per TPS }\end{array}$ & 29,8 & 70,2 \\
\hline Arrival time settings & 32,9 & 67,1 \\
\hline $\begin{array}{l}\text { TPS officers are confirmed to be free of } \\
\text { covid }\end{array}$ & 49,3 & 50,7 \\
\hline $\begin{array}{l}\text { TPS Officers Wearing Standard Personal } \\
\text { Protective Equipment (PPE) }\end{array}$ & 50,7 & 49,3 \\
\hline TPS Is Sterilized Periodically & 37,9 & 62,1 \\
\hline Sterilized Paste Tool Periodically & 35,5 & 64,5 \\
\hline $\begin{array}{l}\text { Voters Must Have Body Temperature } \\
\text { Checked }\end{array}$ & 57,9 & 42,1 \\
\hline $\begin{array}{l}\text { Voters Must Use Masks and } \\
\text { Handsanitizers }\end{array}$ & 59,8 & 40,2 \\
\hline The ink is sprayed not dyed & 31,2 & 68,8 \\
\hline
\end{tabular}

The table above shows that the socialization of health protocols at TPS by organizers has not reached the public optimally. Limiting the number of voters at TPS, setting the hours of voters' arrival, and spraying ink are three of the nine new things at TPS that are not yet known by the public, even though information about the implementation of health protocols at polling stations can reduce public anxiety about the potential spread of
COVID at TPS, which can in turn help achieve the target of voter turnout.

\section{Public Media Usage Patterns of Denpasar City}

As the capital of Bali province, Denpasar has faster internet access and more substantial infrastructure than other areas in Bali. The survey results found that the large number of agent respondents reaching around $82 \%$, had internet access. During the pandemic, the number of the 
Denpasar people using the internet increase. The data shows that $95 \%$ of Denpasar people access the internet everyday and the remaining $5 \%$ access the internet only two to three times a week.

This was also emphasized by respondents that the intensity of internet use during the pandemic also increased. The data shows that $70 \%$ of respondents who accessed the internet said that their intensity during the pandemic cooking period in using the internet had increased. Most of their internet access sources still come from cellular data packages or access via mobile phones by purchasing data from telephone or cellular service providers. The data shows that $64.2 \%$ of respondents access the internet using a cellular data package; $35.2 \%$ stated that they access the internet with a subscription internet system at home. The data also shows that respondents often look for free spots or internet in public areas even though the figure is relatively small, namely $0.6 \%$. This data shows that Denpasar's internet users still rely on cellular data networks rather than fix lines or home subscription services.

Activities that are mostly carried out from home cause the respondents to spare time. Therefore, accessing the internet is the biggest reason for the respondents to fill their spare time. The number of respondents accessing the internet to fill their spare time reaches $35.8 \%$, to look for entertainment $24.4 \%$, to update information $22.7 \%$, and to fulfil obligations such as working and attending school education $15.7 \%$. The data suggests that the internet is a place where respondents are more likely to seek entertainment and fill their spare time, rather than the primary purpose of seeking or updating information.

The internet has various applications, services, and digital platforms that can be accessed either through cellular phones or personal computers. The base platform on the internet which is most frequently searched by respondents is social media. The data shows six pros eight; Sunan respondents stated that social media is the application most frequently used or used while playing the internet. Next, the application most frequently searched on the internet is an entertainment-based application, namely YouTube.

The figures show that $18.3 \%$ of respondents most frequently browse YouTube on the internet. Other platforms or applications that are also frequently explored are search engines such as Google and other Web portals. This data shows that people more often use the internet to socialize on social media and watch entertainment on the YouTube platform, compared to looking for information on online media or other search engines provided by the internet.

Then what are social media platforms that respondents have the most? The survey data shows that all respondents have a WhatsApp conversation application on their respective cellphones. Nearly $77.6 \%$ of respondents stated that they had Facebook accounts and were active on Facebook, while $65.4 \%$ of respondents stated that they had Instagram accounts. Interestingly, $63.7 \%$ of respondents stated that they had LinkedIn accounts. The data also shows that $60.2 \%$ of respondents stated that they had YouTube accounts.

After the WhatsApp conversation application, the second most significant application owned by Denpasar people is the line. The data shows that $44.2 \%$ of respondents stated that they had this conversation platform. For social media which are on the rise like Tik Tok, $18.11 \%$ of respondents have regular accounts in the social media platform.

From the data above, it was known that the social media platform that is mostly owned by the people of Denpasar is the WhatsApp conversation application, followed by Facebook, Instagram, and YouTube. Therefore, if the socialization of Pilkada was carried out online, these social media platforms are considered to be the most frequently used by voters in the city of Denpasar.

The following data is quite impressive; although WhatsApp and social media applications such as Facebook and Instagram are most frequently accessed, the data states that television broadcasts remain the primary source of information for respondents. The data shows that $36.4 \%$ of respondents stated that television was their primary information bucket. The data also shows that Instagram was more often used as the primary source of information than Facebook's social media. Nearly $27.8 \%$ of respondents stated that Instagram was the primary source of information, while only $14.1 \%$ said Facebook was the primary source of information.

Another source of information is online news channels. About $8.11 \%$ of respondents stated that online news was their primary source of information, while $8.4 \%$ of respondents followed the newspaper, $2.2 \%$ used Twitter, and $0.2 \%$ employed community shop, and radio respectively. The data shows that even though there is an increase in internet use, television is still one of the primary sources of information as compared to distribution of information on social media, Instagram, and Facebook.

The following data is quite impressive; although Instagram and Facebook are the most 
frequently accessed sources of information, the level of public trust in information in the Instagram and Facebook is less than conventional media such as television and newspapers because of online news to public figures. From the data above, it was known that $47.6 \%$ of respondents stated that television media is the most trusted source of information for respondents.

The next media most trusted by respondents is newspapers, with $16.9 \%$ of respondents stating that newspapers are the most trusted source of information. Next is the online news channel in Milan's sky, with $8 \%$ of respondents and public figures at $8.8 \%$. Meanwhile, the number of respondents who trusted information through social media such as Instagram was only $6.9 \%$, and only $6 \%$ trusted Facebook.

This data shows that although respondents spend more time on social media and looking for information on social media, the more reliable information is released by television or mass media such as newspapers and online news channels. To decide what channels to use to increase voters' trust in the safety and maintenance of health protocols during the Pilkada and voting, such mass media still have to collaborate.

What television channels should be used in socializing the stages of the Pilkada in the pandemic cookery and socializing the technical health protocols at the polling stations? The data shows that $65 \%$ of respondents are still active in watching television in Denpasar. The local television channel that is the favourite of most people of Denpasar is Bali TV. Eleven out of 16 respondents said they often watch Bali $\mathrm{TV}$. The second favourite channel is TVRI Bali; $11 \%$ of respondents said they often watch TVRI Bali.

Meanwhile, other local television stations did not reach $10 \%$ of respondents, such as Kompas Dewata at $8.6 \%$, MNC Bali at 3.6\%, and NET Bali at $2.11 \%$ of respondents. Other data shows that most respondents watch TV at night. As many as $67.2 \%$ of respondents said they watched television at night. $18.6 \%$ of respondents watched television in the afternoon, $9.8 \%$ of respondents watched television during the day, and the remaining $4.4 \%$ said they watched television in the morning.

Meanwhile, for newspapers or print media, the number of respondents who read newspapers was relatively small, namely only $15 \%$, while $5 \%$ of other respondents stated that they did not regularly read newspapers. Ironically, most respondents, or $74.6 \%$, spent time reading newspapers for about one hour.

The following data shows how is the usage patterns of the WhatsApp conversation application. It was previously stated that all respondents have a
WhatsApp application, and $67 \%$ of the respondents stated that they are members of at least one WhatsApp group. Furthermore, this WAG is one of the channels or media where information spreads very fast. The form of information that is often interesting and read by respondents in the WhatsApp conversation application is in the form of pictures or photos.

The data shows that $50.7 \%$ of respondents stated that they often open links that are shared on WhatsApp in the form of images or photos. This figure is higher than the intensity of opening links that only contain text, which is only $47.6 \%$ of respondents said this. In comparison, video is the next form of content that respondents often open after pictures or photos and text. The figure shows that $43.3 \%$ of respondents often open links shared in the WA group in the form of videos.

Data that is not much different can also be seen in the usage patterns of Instagram social media. Based on data collected, more than $50 \%$ of respondents have the Instagram application. Respondents in the city of Denpasar are quite active in surfing on Instagram, and this can be seen from the high number of accounts they follow and follow, namely in the range of 500 to 750. Data regarding what forms of information are often liked and seen by respondents in the city of Denpasar are information in the form of images. $61.4 \%$ of respondents stated that they often absorb information in the form of images, $59.2 \%$ of respondents stated that they often absorb information in the form of videos, and 50\% read captions from image and video posts.

Similar data can also be seen from the responses of respondents to the content disseminated through social media Facebook. As noted above, Facebook is the third-largest platform owned by respondents in the city of Denpasar. The data shows that $3.5 \%$ of respondents' five stomachs stated that they often see pictures while surfing on social media Facebook. Interestingly, respondents often watch videos on Facebook, 14 months; 3\% of respondents said they often watch videos while surfing on Facebook. This day was followed by reading text activities, with $449.2 \%$ of respondents stating that they often, and only $30.4 \%$ of real respondents often heard audio messages while surfing Facebook.

In the previous section, several indicators have shown little public attention to the 2020 Pilkada in Denpasar City. This needs to be traced to the pattern of public information consumption about Pilkada in Denpasar City. The results of this survey show that the efforts made by the organizers; in this case, the Denpasar KPU, in transforming socialization media from offline 
media to online media have not been entirely successful. Denpasar is a pilot area for Pilkada without plastic waste in Indonesia. Therefore, the use of conventional campaign media such as billboards and banners was greatly suppressed, then replaced by campaign media through social media and online media.
The findings of a survey conducted in September 2020, two months before voting day, show that the Denpasar community still relies on conventional media in obtaining information about the 2020 Pilkada. These data were presented in Figure 6 below.

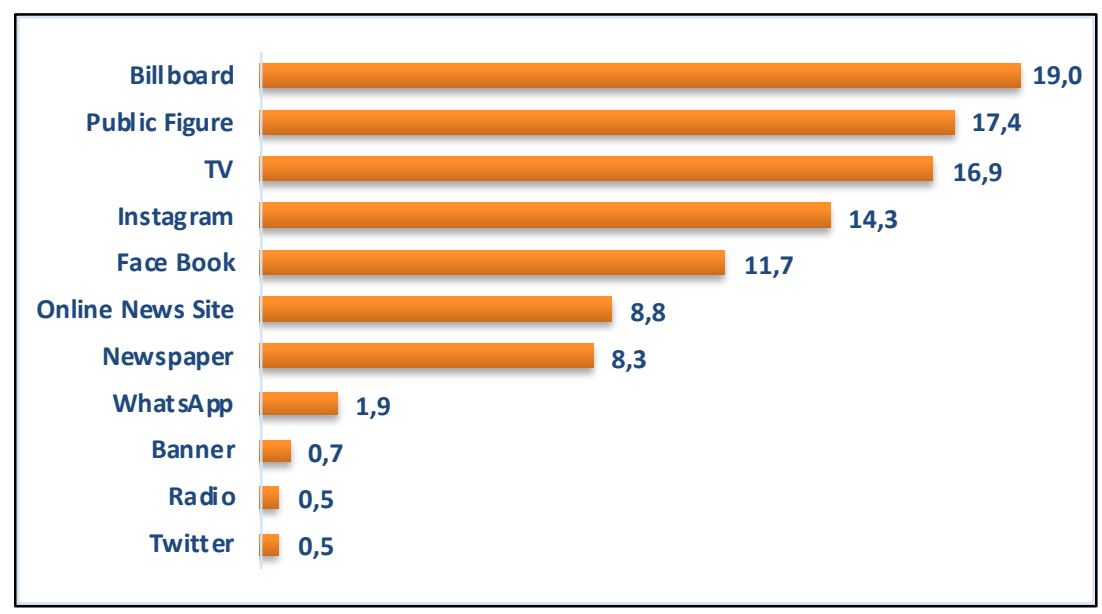

Figure 6. Information Sources about the 2020 Denpasar City Election.

The data above shows that the top three sources of information related to the Denpasar City Pilkada were still occupied by conventional media, namely billboards (19\%), community leaders (17.4\%), and TV (16.9\%). New media that have become the mainstay of organizers in the city of Denpasar during the Pilkada in the pandemic, such as Facebook and Instagram, only occupy the fourth and fifth positions respectively.

Table 2. Voters Who Follow the Official Accounts of Denpasar City KPU

\begin{tabular}{|c|c|c|}
\hline $\begin{array}{l}\text { Following the Denpasar KPU Social Media } \\
\text { Account }\end{array}$ & Yes, I Follow & No, I Don't \\
\hline Face Book & 3,8 & 96,2 \\
\hline Instagram & 2,6 & 97,4 \\
\hline YouTube & 0,5 & 99,5 \\
\hline Tik Tok & & 100,0 \\
\hline Twitter & 0,2 & 99,8 \\
\hline
\end{tabular}

Interestingly, when the data above is examined by looking at how many people in Denpasar follow the official accounts of election organizers in the city of Denpasar, it is found that their number is low. The table 2 presents these findings. The organizer's social media account that was most followed by the public was FaceBook $(3.8 \%)$. This figure is also petite compared to those who claim to have received information on the Denpasar Pilkada via FaceBook. This means that most voters who obtain information on the Denpasar Pilkada through FaceBook do not access it through the organizer's official FaceBook. This pattern should be an introductory note for the organizers in determining which communication model to choose in the remaining two months. Relying on Pilkada socialization online and on official accounts of organizers may be less effective.

Amid this Pandemic, when the communication model was shifted online, the people of Denpasar, which in fact are urban communities, have not fully accepted it. Voters in this city still state that they feel they still need conventional media in obtaining information on Pilkada. The most interesting finding from a series of media offered to the public is that webinars or online seminars are less attractive to the public in the context of Pilkada in the midst of a pandemic. Data regarding this can be seen in the table below. 
Table 3. The Need for Socialization Media for Pilkada in Denpasar

\begin{tabular}{|l|c|c|}
\hline \multicolumn{1}{|c|}{$\begin{array}{c}\text { Is the Following Social Media Still } \\
\text { Needed? }\end{array}$} & Still Needed & No Longer Needed \\
\hline Billboard & 96,4 & 3,6 \\
\hline Banner & 90,7 & 9,3 \\
\hline Sticker & 58,6 & 41,4 \\
\hline T-shirt & 67,4 & 32,6 \\
\hline Simakrama (Discussion) & 77,4 & 22,6 \\
\hline Candidate Debates & 88,3 & 11,7 \\
\hline TV Advertisement & 85,5 & 14,5 \\
\hline Radio Ads & 77,9 & 22,1 \\
\hline Print Media Advertising & 91,2 & 8,8 \\
\hline Online Media News & 87,4 & 12,6 \\
\hline Face to face & 43,3 & 56,7 \\
\hline Online/ Webinar & 39,0 & 61,0 \\
\hline
\end{tabular}

Next will be explained which media should be the choice in socializing the Election Stages and the technical implementation of Health Protocols in polling stations conducted by the KPU. The data above shows that online media is still needed. From the survey results, it is known that the online media most accessed by voters is bali.tribunnews.com, namely by $28.3 \%$ of respondents. The next online media most accessed by respondents was kompas.com, with $23.8 \%$ of respondents. They were then followed by Nusa Bali.com with $21.2 \%$ of respondents, balebengong.id with $10 \%$ of respondents, bali.antara news.com for 8.8 respondents and beritabali.com with $9.5 \%$ of respondents.

From the data above, it can also be concluded that the online media channel that is widely accessed by the people of Denpasar is the Canal, which is part of the big media in Indonesia, which is then followed by large media at the local level.

The communication process carried out by the KPU to voters in the Pilkada is expected to get a response where there are voters who believe it, and the level of voters in Denpasar who come to the meets the target.

So it becomes imperative in a political communication process a useful communication model. From the data above, it was known that, in a pandemic, Pilkada organizers need to think creatively so that democracy in their regions can still run according to the principles of democracy but also meets health protocol standards so that voters do not fall victim to regional elections during the Pandemic.

The communication model proposed based on the data above is a combination of communication via the internet or online and communication via outside the network or offline.

Offline Model. The data shows that the people of Denpasar city still need outdoor media to obtain information about the Denpasar mayoral election. The media that can be used are billboards and banners. Even though it seems to be very traditional, the data shows that the public gets the most information about the elections through the billboards installed by the KPU of Denpasar city. However, these billboards still have a weakness in that they cannot provide details of information they want to convey to voters.

Other communication models can also use conventional media channels such as print media and television, and online media portals. For online media, it mainly targets media that is widely accessed by the people of Denpasar, such as bali.tribunews.com, kompas.com, nusabali.com, bali.antaranews.com, and beritabali.com.

Another media channel that can be used in socializing is this local television channel, the television most watched by people in Denpasar, namely Bali TV and TVRI Bali. The communication model through the mass media is still considered important for the community because it is through mass media that the public believes more in the information presented.

Online communication model. The online communication model, or through a network, is a communication model through the internet and new media such as social media. The WhatsApp conversation application is the most widely used channel, but WhatsApp's characteristics are that it is more personal than other social media.

In WhatsApp, the communication model that can be done is to pack information that is quite simple, which is then disseminated to the maximum through the account and Whatsapp group. Meanwhile, for social media such as Instagram and Facebook, the KPU of Denpasar City should use content in the form of images because this content is the most opened and viewed content compared to only writing or video/audio. 
What should be noted in the use of the online communication model via Instagram and Facebook is the low number of followers or followers on the official Instagram and Facebook accounts belonging to Denpasar. It is necessary to collaborate with accounts that already have many followers in the city of Denpasar. The study of communication has mentioned a theory called twostep flow of communication or two levels of communication.

Whereas in a communication process, information from communicators is often not directly accepted by the public but through other parties who can convey the information to the public. So the online communication model through Facebook and Instagram should use a twostep flow of communication model using accounts that already have many followers as opinion leaders or mediators to voters in the city of Denpasar.

The next model is the most accepted traditional model of communication, namely through community leaders. The existence of community leaders was still considered adequate. It is one of the most reliable information for the community, so the KPU's socialization can be assisted by community leaders to convince that it will increase voters' understanding about the elections during the pandemic.

So the communication model used to socialize the election stages and the technical health protocols in TPS is a combination of online and offline communication models to fulfil the need for information about the Pilkada of Denpasar city.

\section{Conclusion}

Even though the use of internet media is increasing, people still need a mass communication model because it is considered more trustworthy than social media. In socializing the stages and the technical health protocols at TPS, they cannot entirely focus on socialization with the online system, and people still need information they trust from offline media.

\section{References}

Amirudin, Z. (2015). Model Communication Enggagement dalam Komunikasi Politik Calon Legislatif dalam Pemilu 2014. Jurnal Informasi, 45(2), 115-124.

Baccini, L., Brodeur, A., \& Weymouth, S. (2020). The COVID-19 Pandemic and the 2020 U.S. Presidential Election. IZA DP No. 13862.

Beritasatu.com. (2020). Pilkada di Tengah Pandemi. Beritasatu.Com.

Bungin, B. (2008). Metodologi Penelitian
Kuantitatif: Komunikasi, Ekonomi, Kebijakan Publik Serta Ilmu-Ilmu Sosial Lainnya, Jakarta: Kencana

Harison, L. (2009). Metode Penelitian Politik, Jakarta: Kencana

Hasfi, N., Usman, S., \& Santosa, H. P. (2017). Representasi Kepemimpinan Calon Presiden Di Twitter. Jurnal ASPIKOM, 3(2), 270284.

Hergianasari, P. (2020). Electoral Distancing: Alternatif Penyelenggaraan Pemilihan Kepala Daerah 2020 Ditengah Covid-19 Di Indonesia. Magistrorum Et Scholarium: Jurnal Pengabdian, 01(1), 112-121. https://ejournal.uksw.edu/jms/article/view/4 024

Howe, N. \& Strauss, W. (1991). Generations: The History of America's Future, 1584 to 2069, https://www.lifecourse.com/assets/files/Wh y\%20Generations\%20Matter\%20LifeCours e\%20Associates\%20Feb\%202012.pdf

James, T. S., \& Alihodzic, S. (2020). When is it democratic to postpone an election? elections during natural disasters, covid-19, and emergency situations. Election Law Journal: Rules, Politics, and Policy, 19(3), 344-362. https://doi.org/10.1089/elj.2020.0642

KIM, S. C. (2020). South Korea's 2020 Election Amid COVID-19. East Asian Policy, 12(03), 49-62. https://doi.org/10.1142/s179393052000022 7

Kompas.com. (2020). Komisi II Minta Paslon yang Melanggar Protokol Kesehatan Didiskualifikasi.

Mars, D. dan Stoker, G. (2010). Teori dan Metode Dalam Ilmu Politik, Bandung: Nusa Media

Meyliana, I. F., \& Erowati, D. (2020). Menakar Partisipasi Politik Masyarakat Kabupaten Tana Toraja Terhadap Pemilihan Kepala Daerah (Pilkada) Tahun 2020. Jurnal Academia Praja, 3(2), 168-181. https://doi.org/10.36859/jap.v3i2.183

Moraru, V., \& Rusu, L. (2017). New Media - the Reforming Factor of Political Communication. International Journal of Communication Research, 7(1), 50-57.

Murwani, E. (2018). The Impression Management Strategy of the Candidates of Governor-Vice Governor of DKI Jakarta on Social Media. Jurnal Komunikasi Ikatan Sarjana Komunikasi Indonesia, 3(2). https://doi.org/10.25008/jkiski.v3i2.219

Mutiarasari, N. N. and R. H. (2020). Supervision of Bawaslu Pemalang Regency in the 2020 Regional Head Election. Law Reform, 16(2), 
264-275.

Persada, I.S.A., Wisnaeni, F. (2020). Dampak Pandemi Covid-19 Modernisasi dan Digitalisasi Komisi Pemilihan Umum Republik Indonesia (KPU-RI). Jurnal Ilmiah Galuh Justisi, 8(2), 186-203.

Sahputra, D,. Muda, I., Hidayat, T.W., Waridah. (2020). Social Media and Civil Society in The Governor's Election of North Sumatera 2018. Jurnal Komunikasi Ikatan Sarjana Komunikasi Indonesia. Vol 5 (1). 10-17

Santoso, D. H., Aziz, J., Pawito, Utari, P., \& Kartono, D. T. (2020). Populism in new media: The online presidential campaign discourse in Indonesia. Gema Online Journal of Language Studies, 20(2), 115133. https://doi.org/10.17576/gema-20202002-07

Saraswati, M. S. (2018). Social Media and the Political Campaign Industry in Indonesia. Jurnal Komunikasi Ikatan Sarjana Komunikasi Indonesia, 3(1). https://doi.org/10.25008/jkiski.v3i1.124

Vaus. D A Sydney, A. and U. (1991). Surveys in social Research. 